\title{
Eukaryotic Translation Initiation Factor 1A, X-Chromosomal
}

National Cancer Institute

\section{Source}

National Cancer Institute. Eukaryotic Translation Initiation Factor 1A, X-Chromosomal.

NCI Thesaurus. Code C131317.

Eukaryotic translation initiation factor 1A, X-chromosomal (144 aa, $\sim 16 \mathrm{kDa}$ ) is encoded by the human EIF1AX gene. This protein is involved in the modulation of translation. 